\title{
Judicial Review of Government Actions in China
}

Wei Cui, Jie Cheng and Dominika Wiesner

\section{(2) OpenEdition}

\section{Journals}

Electronic version

URL: http://journals.openedition.org/chinaperspectives/8703

DOI: 10.4000/chinaperspectives.8703

ISSN: 1996-4617

Publisher

Centre d'étude français sur la Chine contemporaine

\section{Printed version}

Date of publication: 20 March 2019

Number of pages: $35-44$

ISSN: 2070-3449

\section{Electronic reference}

Wei Cui, Jie Cheng and Dominika Wiesner, « Judicial Review of Government Actions in China », China Perspectives [Online], 2019-1 | 2019, Online since 19 March 2020, connection on 19 December 2020. URL : http://journals.openedition.org/chinaperspectives/8703 ; DOI : https://doi.org/10.4000/ chinaperspectives.8703 


\title{
Judicial Review of Government
}

\section{Actions in China}

\author{
WEI CUI, IIE CHENG, AND DOMINIKA WIESNER
}

\begin{abstract}
The judicial review of government actions is often used as a bellwether of the government's attitude towards the rule of law in China. Accordingly, in gauging the direction of legal reform in the Xi era, media reports have highlighted changes in litigation against government agencies as evidence of positive movement towards greater rule of law. We provide a selective review of changes in China's administrative litigation system in the last few years, giving special attention to the amendment in 2014 of the Administrative Litigation Law (ALL), and a 2018 Supreme People's Court Interpretation of the same statute. In our view, the question of whether lawsuits might be brought against the government has arguably been superseded in importance by the question of how courts will decide such lawsuits. And the generic notion of judicial independence itself no longer sheds sufficient light on actual and possible judicial responses. Using the purportedly expanded scope of review of informal policy directives as an example, we show that symbolism-motivated advocacy to improve the administrative litigation in China may come at the expense of protecting the non-symbolic functions of judicial review, e.g., the coherence of law and consistency in the delivery of justice.
\end{abstract}

KEYWORDS: Judicial review, Chinese law, standard of review, scope of review, Supreme People's Court.

\section{Introduction}

C hina's laws and policies on the judicial review of government actions are often presented as an important bellwether of the government's attitude towards the rule of law. ${ }^{(1)}$ Accordingly, in the last few years, in gauging the direction of legal reform in the Xi Jinping era, media reports have highlighted changes in litigation against government agencies as evidence of positive movement towards the greater rule of law, albeit only contradicted by other evidence of political repression and increasing authoritarianism. (2) Regardless of whether the institution of judicial review can bear the symbolic weight that has thus been vested in it - we believe there are many reasons to be sceptical (Cui 2017) - the last few years have indeed witnessed very momentous changes in China's administrative litigation system. In 2014, the Administrative Litigation Law (ALL) received its first amendment since its original adoption in 1989; the newly (and extensively) amended statute took effect on $1^{\text {st }}$ May 2015. (3) In 2018, China's Supreme People's Court (SPC) published a lengthy Interpretation on the Application of the Administrative Litigation Law (hereinafter the "2018 SPC Interpretation"), which replaced and substantially revised previous interpretations and ushered in a number of important doctrinal and institutional innovations. More generally, reforms carried out since 2014 of the Chinese judicial system - including especially the centralisation (to the provincial level) of court financing, re-allocation of jurisdiction to higher courts, the creation of new supra-provincial circuit courts, and dramatic changes to judges' career incentives - all have had direct impact on the administrative tribunals that hear lawsuits against government agencies.

The empirical reality of judicial review makes these statutory, doctrinal, and institutional changes even harder to ignore. The number of first-instance lawsuits against government agencies in China surged from 123,194 in 2013 to 230,432 in 2017 , an increase of $87 \%$; and the number of second-instance disputes (i.e., appeals) from such lawsuits increased even faster $-207 \%$, or from 35,222 to 108,099 . (4) On a per capita basis, the volume of administrative litigation in China already surpasses that of Taiwan, ${ }^{(5)}$ and no doubt of some other countries where both democratic accountability and judicial independence are regarded as well established.

In this essay, we provide a selective review of these recent changes in the doctrines and procedures of judicial review. Our review adopts a pragmatic and comparative approach. In our view, the question of whether lawsuits might be brought against the government has arguably become less interesting than the question of how courts will decide such lawsuits. And the generic notion of judicial independence itself no longer sheds sufficient light on the range of actual and possible judicial responses. However, many media and scholarly commentaries (both Chinese and Western) on judicial review in China remain fixated on symbolic values. Arguably, this fixation has given rise to institutional arrangements that threaten to diminish, rather than enhance, judicial authority.

As a particular example, we examine controversies surrounding the scope of review under the ALL in sections entitled "A comparative perspective on the scope of review" and "Innovations in the 2018 SPC interpretation" below. Conventional wisdom has it that the scope of judicial review in China

1. The Chinese-language literature on administrative litigation in China is too voluminous to cite here. We cite specific relevant sources below. For some recent scholarly contributions in English we refer to He (2018); Liebman et al. (2017); Cui and Wang (2017).

2. E.g., lan Johnson, "China Grants Courts Greater Autonomy on Limited Matters," The New York Times, 2 January 2016, https://nyti.ms/1YXhQ7F (accessed on 1 September 2018); "Justice served, sometimes: For some plaintiffs, courts in China are getting better," The Economist, 30 September 2017, 424(9060): 57.

3. Hereinafter we refer to the amended Administrative Litigation Law as the $2015 \mathrm{ALL}$, and to the statute before its 2014 amendment as the 1989 ALL.

4. All statistics cited in this essay for 2013-2016 are from the China Law Yearbook. 2017 litigation statistics are based on unpublished data provided to the authors by the SPC.

5. For case volume in the Taiwanese administrative court system in recent years, see statistics from the Judicial Yuan of the Republic of China (Taiwan), http://www.judicial.gov.tw/juds/report/sg2.htm (first instance) and http://www.judicial.gov.tw/juds/report/sc-2.htm (appeals) (accessed on 1 September 2018) 
is too narrow. We show that from a comparative administrative law perspective, the scope of review under pre-2015 practice was in fact quite normal. Rather, it is the effort to extend such scope since 2015 that is unusual by international standards. At the same time, we show that an issue that has been central to the practice of administrative law in liberal democracies - namely the standard of review that courts adopt when examining the justifiability of government actions - has often been ignored both in institutional reform in China and in scholarly commentaries. Registering this issue indeed allows us to identify an important rolling back of judicial authority implied by recent reforms. This development raises the possibility that symbolism-motivated advocacy to improve administrative litigation in China may come at the expense of protecting the nonsymbolic functions of judicial review, and of guaranteeing what judges really care about, i.e., the coherence of law and consistency in the delivery of justice.

Before delving into this particular controversy, we provide background information regarding the ALL amendment (and its subsequent SPC elaboration) and the impact of judicial reform on administrative litigation in Section I. The conclusion offers some reflections on the ALL's evolution.

\section{The 2015 ALL and post-2013 judicial reform}

\section{Background}

The revision of the $1989 \mathrm{ALL}$ had been the subject of a decade-long discussion sustained by top-down reform proposals from the Standing Committee of the National People's Congress (NPCSC) as well as the SPC. In December 2003, the $10^{\text {th }}$ NPCSC listed the revision of the ALL as a Category II item in its legislative plan - meaning that the NPCSC would work on a draft without deliberating on it immediately. It was not until December 2013 that the legislative plan of the $12^{\text {th }}$ NPCSC made ALL revision into a Category I item, to be deliberated in the current term. Systematic research on the ALL's revision followed these two inclusions in the NPCSC legislative agenda, especially between 2005-2007 and then 2012-2014 (Zhang 2015: 66). (6)

The SPC played an important role in this process. A book for which senior SPC judge Jiang Bixin 江必新 served as chief editor and co-author, Perfection of China's Administrative Litigation System: A Practical Study for an ALL Revision, became a classic (Jiang 2005), and helped to frame many of the major issues in the debate in this area. ${ }^{(7)}$ The view expressed in his book was as much institutional as it was personal. (8) Jiang identified four major issues as critical to reforming administrative litigation: (1) empowering the administrative tribunal, (2) nurturing a profession of administrative law judges, (3) achieving efficiency and inclusiveness of adjudication, and (4) enhancing jurisdictional flexibility (Jiang 2005: 9-12). The SPC's influence on the ALL revision is visible through both the issues emphasised by the NPCSC during its deliberations and the structure of the revisions to the law. For example, when Xin Chunying 信春鹰, vice director of the NPCSC Legislative Affairs Office, introduced the Draft Revision of the ALL on the last day of 2013, she mentioned the "three difficulties of adjudication" (i.e., of filing a case, of adjudicating a case, and of enforcing a decision rendered), which echoed the "three difficulties" originally formulated by Jiang in 2005 (Jiang 2005: 9-10). Many provisions of the Draft Revision were also anticipated in the 11 topics that structured jiang's book. Nonetheless, among the four critical issues identified by jiang (and his SPC colleagues), the NPCSC prioritised issues of adjudication (including the so-called three difficulties), and hesitated to proceed with the first two structural issues (i.e. the roles of administrative tribunals and of judges).

Scholars and other actors expressed somewhat different ideas about the ALL revision. According to a survey conducted after the release of the Draft Revised ALL, topics most frequently mentioned as being of interest included: (1) the scope of review, i.e., typology of cases and disputes reviewable; (2) the distribution of cases among different levels of courts; (3) the codification of the role of mediation in the litigation process; (4) public interest litigation, and (5) the review of informal policy documents (IPDs, guifanxing wenjian 规范性文件) (Li 2016: 114). (9) While almost all of these topics can be found in Jiang's 2005 book or in the articles or books of other SPC judges (Li, Wang and Liang 2013:69), (10) they lacked the structural and institutional focus that characterised the SPC reformers' proposals. Thus, public commentaries are of interest mainly because they highlighted the exceedingly conservative approach of the 2013 NPCSC Draft, which for the most part merely compiled existing judicial interpretations (Li 2016: 111). In any case, discussions regarding structural court reform were largely limited to the administrative law community.

Entering 2014, political initiatives of the Chinese Communist Party (CCP) accelerated the process of ALL reform. First, the CCP adopted the "Decision on Several Important Issues for Full-fledged Deepening Reform" in November 2013. Then the Leading Group on Comprehensively Deepening Reform (LCCDR) was established, headed by Xi Jinping. On February 28, 2014, the LGCDR issued the Opinions and Division of Labour to Enforce Deepening Judicial and Social Reform. This document laid the foundation for the system for limiting the proportion of judges in court staffing (faguan yuan'e zhi 法官员额制), as well as for creating cross-region/district courts. ${ }^{(11)}$ In October 2014, the CCP passed the Decision on Facilitating Fully-Fledged Rule of Law, which, among other things, urged reforming the docketing system from implementing substantive review to a mere registration system.

In response to these new policies as well as public criticism, the NPCSC published an updated Revised Draft in 2014, amending 61 of the 75 articles of the $1995 \mathrm{ALL}$. In addition to the original proposal, the draft highlighted the following arrangements: (1) the case registration system, (2) the responsibility of agency leaders to attend court hearings, (3) making administrative reconsideration bodies defendants, (4) sanctioning improper administrative acts, and (5) judicial review of IPDs. Among these, only the proposal for the case registration system had been anticipated by the 2013 Draft; other new proposals could all be seen as responding to the CCP's judicial reform policy. This draft was deliberated by the NPCSC and passed with minor changes on 1 November 2014 (Qiao 2014).

6. Before 2003, research on and criticism of the 1989 ALL were sporadic.

7. Jiang participated in drafting the $1989 \mathrm{ALL}$ and was the director of the SPC's Administrative Division between 1999-2002, becoming a SPC Vice President by 2003. He was appointed Vice Director of the Constitutional and Legal Committee of the NPC in March 2018, right after the 2018 Judicial Interpretation was published.

8. The book was co-authored with other SPC judges, including Cai Xiaoxue, Gan Wen, Duan Xiaojing, and Liang Fengyun.

9. See the section entitled "A comparative perspective on the scope of review" below for an extended discussion of pre-2015 practice in the review of IPDs.

10. ALL experts also held rather philosophical debates about whether a through re-write or an incremental revision was appropriate, and whether an independent administrative court system should be put in place.

11. The SPC promptly echoed this policy with its fourth Five-year Reform Plan in July 2014, emphasising the judges' quota system, case registration, and cross-region court experiments. 


\section{An overview of the 2015 ALL}

The 2015 ALL kept the original structure of the 1989 ALL, but was elaborated and enriched to contain 103 articles. Some major revisions are summarised below (Tong 2015: 22-7).

\section{Incremental expansion of the scope of review}

Under the $2015 \mathrm{ALL}$, individuals, organisations, or legal persons may file a lawsuit if they believe that an "administrative action" violates their legal rights and interests (Article 2). The term "administrative action" replaced the term "concrete administrative action" in the 1989 ALL, although this drafting change has little significance in itself in expanding the scope of review. This is basically because the $2015 \mathrm{ALL}$ retains a provision (Article 13) from the 1989 ALL that excludes four categories of government actions from judicial review - including formal and informal rulemaking. More substantively, Article 2(2) extends the definition of "administrative action" to include decisions made by organisations authorised to exercise administrative mandates, such as universities and some regulatory bodies. In addition, Article 12 details 11 areas in which legal proceedings may be launched against governments, making explicit reference to violations of agreements on land and housing compensation, unlawful alteration or rescission of agreements on commercial operations franchised by the government, and illegal restriction of an individual's physical freedom. While all government actions encroaching on the personal and property rights of plaintiffs can be challenged (before and after 2015), the new statutory enumeration seemed to identify areas where the need to cope with social resentment and unrest is most urgent.

The SPC further elaborated the scope of judicial review in the 2018 SPC Interpretation. The Interpretation sets out another ten categories of exclusions from review, all of which had been grey areas in which judges made inconsistent decisions: (i) public or national security investigations pursuant to the criminal procedure law; (ii) mediation and arbitration as provided by law; (iii) administrative guidance; (iv) reaffirmations of previous decisions; (v) administrative actions without external effect; (vi) preparatory and deliberative acts; (vii) enforcement of court decisions; (viii) internal supervisory acts; (ix) decisions against petitions; and (x) administrative acts that have no actual effect on individuals and legal persons. Together with the 2015 ALL, the 2018 SPC Interpretation now provides clearer statements about the scope of reviewable issues.

Terminologically, one might say that these are all issues relating to causes of action. Discussions of the "scope of review" debate in China also sometimes touch on what issues courts are allowed to render decisions on. We discuss courts' new ability to review IPDs in the next section ("A comparative perspective on the scope of review").

\section{Clarification on standing}

The 1989 ALL's standard for standing was formulated subjectively - one may bring a suit if one "considers" that a concrete administrative action infringes on one's lawful rights and interests (Article 2). A 2000 SPC's Interpretation of the $1989 \mathrm{ALL}$ stipulated that only those who possess legal rights and interests may bring a case - which was characterised by some as overly narrow (Jiang 2013: 9). The $2015 \mathrm{ALL}$ aimed to resolve this controversy. It provides that a person subjected to an administrative action or any other person with an interest in the administrative action has the right to file a complaint (Article 25). The phrase "with an interest" is considered to be broader than "with legal rights and interests," but narrower than "who considers his interest [violated]" (Tong 2015: 25).

The 2018 SPC interpretation provides further rules to identify eligible plaintiffs under Article 25 of the 2015 ALL. Parties newly specified as eligible include, for example, (i) persons who file a complaint to an agency to maintain their lawful rights and interests and who wish to dispute the processing agency's response (Article 12(5)); (ii) a creditor where an agency action towards a debtor damages the creditor's claim, and where the agency is legally required to provide protection or give consideration to the creditor's rights (Article 13); (iii) the founder or capital contributor to a non-profit entity that deems an agency action to infringe upon the lawful rights and interests of the entity (in which case the founder or contributor may file a complaint in its own name) (Article 17); and (iv) an owners' committee of jointly owned property, or a qualified owner (or owners) of such property (Article 18).

However, the revised ALL refrains from giving non-government parties the right to commence public interest litigation. During the debate on the ALL revision, both civil society and public prosecutors were considered potential plaintiffs for public interest litigation (Jiang 2013: 16). Before 2015, courts also accepted cases brought by non-governmental organisations. ${ }^{(12)}$ Indeed, in 2014, the Environment Protection Law was revised and Article 58 provides that registered social organisations may bring public interest litigation. However, in a 2017 amendment of the ALL, the NPCSC added paragraph 4 to ALL Article 25, providing that the procuratorate may bring a suit when responsible administrative agencies engage in conduct (or fail to take action) in violation of the law, in areas of environmental protection, food and drug security, state assets protection, and state land use right transactions, or where national or public interest may be harmed. The $2017 \mathrm{ALL}$ revision therefore excludes civil society from public interest administrative litigation, although public interest litigation through civil proceedings is still possible.

\section{Improving adjudication}

The $2015 \mathrm{ALL}$ codifies the case registration system that began to be implemented in May 2015 for both civil and administrative cases, which made courts more accessible for potential plaintiffs. Previously, courts would accept cases only after a substantive review of the filed documents. Many cases were screened out with no reasons given, and sometimes for being too "sensitive" or "complicated." (13) The new case registration system requires that all complaints be registered and filed automatically with only minimal review. If a court declines to take a case, it must issue a reason for the rejection, and the decision can be challenged.

The revised ALL also reforms the allocation of jurisdiction, allowing intermediate courts to adjudicate disputes involving government agencies above the county level (Article 15). Article 18 further authorises the SPC and high courts to designate certain courts to adjudicate disputes across jurisdictions. While the statute contemplates no move to independent administrative courts, the door is not completely closed: both the Beijing Fourth Interme-

12. For example, there was a 2009 case brought by All-China Environment Federation against Guizhou Qingzhen City Land Resource Bureau (Jin 2014: 70).

13. In a survey conducted in $2013,19.4 \%$ of participant judges admitted that they have rejected cases that should have been accepted (Lin and Song 2013). Note that media reports, such as that in The New York Times (Johnson supra note 2) - claiming that "by the mid-2000s, about 60 percent of these cases were rejected outright by courts, according to government statistics" - often fail to provide the source of cited statistics. 
diate Court and the Shanghai Third Intermediate Court were created in 2015 , based on the original railroad court model, ${ }^{(14)}$ and mainly deal with administrative cases in Beijing and Shanghai, respectively.

The $2015 \mathrm{ALL}$ also adds mediation as a type of remedy. A traditional theory had it that government agencies were to enforce the law and should be prohibited from bargaining with individuals. That theory, however, has become anachronistic with government powers extending to many economic areas. Contemporary studies provide evidence that mediation mitigates conflicts and reduces administrative costs. ${ }^{(15)}$ The 2015 revision reflects this new understanding of the functions of mediation in public law.

\section{Court leverage on agency defendants}

The revised ALL requires that the person in charge of the defendant agency appear in court or designate staff members to do so (Article 3). If the agency refuses to perform acts required by a judgment, the person in charge may be detained; and if the circumstances of such refusal are serious and constitute a crime, criminal liability will be imposed on the person in charge (Article 59). Moreover, the revised ALL provides that the court may fine the responsible government official 50-100 RMB each day if he or she fails to comply with the court decision (Article 96(2)) and may also publicise the non-compliance of the government agency (Article 96(3)). These unique provisions clearly aim to deter government misconduct through social and psychological pressures.

\section{Reform of the judiciary in general}

As already discussed, the revision of the ALL benefited from the CCP's general judicial reform effort after 2013, especially with respect to case registration and new arrangements for jurisdictional assignment. Indeed, the revision of the ALL must be considered part of China's general judicial reform. Before 2013, the SPC's various reform plans had stalled due to reform measures being perceived as too aggressive or even as possibly eroding CCP authority. For example, the second Five-year Plan (2004-2008) expressly promoted judicial independence and judicial authority. Yet it was precisely during this period that the SPC had to repeal its 2001 judicial interpretation on the Qi Yuling case (a landmark case displaying judicial activism in constitutional interpretation). By 2013, the Party's Propaganda Department had even explicitly designated "judicial independence" as a politically incorrect term. ${ }^{(16)}$ Moreover, systematic institutional changes, especially in terms of court organisation, personnel reform and financial security, required political support from the NPC (for parliamentary authorisation of fundamental organisational changes), the State Council (for court finance), as well as from the Party. Without broad political support, previous judicial reforms invariably ended up focusing narrowly on improvements of professionalism and procedure. ${ }^{(17)}$

In contrast, the SPC released its Fourth Judicial Reform Plan (2014-2018) after the CCP issued its own rule of law policy (in October 2014): the new plan functioned as a detailed implementation strategy for the Party's new policy, and can claim to directly reflect the Party's preferences. As a result, this new round of judicial reform was able to achieve crucial goals that eluded previous reformers.

Some aspects of structural judicial reform specifically addressed administrative litigation. These include (1) creating circuit courts of the SPC to adjudicate important, cross-jurisdictional cases (both civil and administra- tive); (2) creating lower-level, cross-region courts to adjudicate environmental law, bankruptcy, important administrative and other types of cases that might encounter local interference; and (3) encouraging intermediate courts to take on first-instance administrative cases and allowing basic level courts to swap jurisdictions on administrative cases. ${ }^{(18)}$ All three measures aim to prevent local interference and enable relatively independent and neutral adjudication. ${ }^{(19)}$

Other aspects of judicial reform are also relevant for administrative litigation. These include, for example, promoting judicial transparency by introducing open trial and the online publication of court decisions (Liebman et al. 2017). They also include screening out over $60 \%$ of court employees that previously had the title of judges, many of whom were underqualified. (20) The process of reappointing judges as qualified judges was still ongoing in 2018.

It is worth pointing out that some of the reform measures - especially the case registration system and scheme to disqualify $60 \%$ of all judges went against the preference of the judiciary, and were promoted as a part of the CCP's political agenda. Whether this will produce some kind of strategic backlash from the courts is yet to be seen. Also, although "de-localisation" is a clear goal of the reform, it is not clear if the central government will provide necessary financial support to lower-level courts. Moreover, even the new cross-region courts (funded by the Central government) are still expected to adopt the existing bureaucratic structure, where the court president can intervene in all cases adjudicated and thus threaten independent adjudication.

\section{A comparative perspective on the scope of review}

Having provided an overview of the ALL's recent amendments and the aspects of judicial reform that bear on administrative litigation, we now turn to an issue that exemplifies divergent ideological approaches to enhancing judicial review in China.

Under pre-2015 law and practice, Chinese courts' power to review regulations and other policy directives adopted by executive branch agencies took three main forms. First, if a regulation (guizhang 规章) was offered as the legal basis of agency action, a court must determine whether the regulation was legal and in force before giving it application as law. ${ }^{(21)}$ Second, if some "other normative document" (qita guifanxing wenjian 其他规范性 文件, which we refer to as informal policy document or IPD here) was offered as the legal basis of an agency action, such document had no binding force on courts. Courts could nevertheless give it effect after reviewing and

14. Railroad courts used to be affiliated with Ministry of Railroad and had cross-region jurisdictions.

15. Hu and Tang present seven local courts that experimented with administrative mediation starting from 2006 (Hu and Tang 2011: 5, see especially footnote 4).

16. Circular on the Current Ideological Field, in Mirror, August 2013 (43), Hong Kong. The circular was famous for listing seven prohibited terms, or "seven no's" in China.

17. Indeed, as a backlash to the Second Five-year Reform, the SPC's Third Five-year Reform emphasised popular responsibility.

18. See, 2013 SPC Notice on Carrying Out the Pilot Work of Centralising Jurisdiction in Administrative Cases; 2014 SPC Guiding Opinion on Centralised Adjudication of Administrative Cases on a CrossAdministrative-Region Basis.

19. Since 2015, the SPC has created six circuit courts, as well as two cross-district courts in Beijing and Shanghai.

20. Only $39 \%$ of the judges under the previous status quo will be able to keep their titles as judges (Gao 2015).

21. 1989 ALL Article 53, par. 1; Shanghai Meeting Minutes, Section 1, par. 1. 
confirming its legality, validity, reasonableness, and appropriateness. (22) That is, legality was not sufficient for an IPD to be given effect: a court had discretion to disregard IPDs based on judgments about their reasonableness and appropriateness - or it could even simply disregard them altogether, without review. Third and finally, there was a set of circumstances in which a court might suspend judicial proceedings and seek resolution of conflicts among formally binding legal rules, through interlocutory procedures that transmited questions to the executive branch. One such circumstance was irresolvable conflicts among ministerial and subnational regulations, (23) but the interlocutory procedure was also available for a wider range of conflicts among other types of formally binding law. (24)

It has long been conventional wisdom among commentators on Chinese administrative law that these parameters for judicial review were too restrictive (He 2018; Tong 2015). The restrictions most frequently criticised were two. First, Article 12(2) of the 1989 ALL explicitly ruled out lawsuits brought merely to challenge "administrative statutes and regulations, or decisions and orders with general binding force formulated and announced by administrative entities." That is, agency adoption of formal or informal rules - colloquially labelled "abstract administrative actions" - could be causes of action, even if the rules adopted were suspected to be illegal, unreasonable, or otherwise flawed. ${ }^{(25)}$ As discussed, this provision remains unchanged in the $2015 \mathrm{ALL}$, despite the fact that the 2014 amendment no longer refers to "specific administrative actions" in its provisions on permissible causes of action.

Second, Chinese courts could not invalidate or "strike down" agency rules (formal or informal) in the sense of precluding them from future enforcement. Instead, they only had the choice (for the most part) of not applying an invalid or otherwise unacceptable rule in a given case. This remains the case under the $2015 \mathrm{ALL}$, although, as discussed below, the SPC has adopted some extraordinary measures to put the executive on notice of the need to change invalid IPDs.

Conventional wisdom has it that these two restrictions rendered the law of administrative litigation in China defective; such wisdom partially fuelled the ALL revision, and will no doubt continue to colour criticism of the ALL in the future. From a comparative perspective, however, this conventional view is puzzling and indeed seems confused. Both types of restrictions described above - on causes of action and on available remedies - are quite common in modern liberal democracies that enjoy strong rule of law. Both also have generally applicable institutional explanations. Because the conventional wisdom has had a direct impact in the design of China's public remedial system, identifying its errors is crucial for appreciating how radical some aspects of the ALL are. For example, the process, described in the next section, by which courts are now expected to offer "judicial recommendations" for the repeal, amendment, or suspension of IPDs is, to our knowledge, internationally unique.

\section{Limitations on remedies provided by civil law courts}

The logic of the two restrictions on the scope of judicial review is best explained in reverse order. First, there is an obvious explanation why Chinese courts may not be permitted to "strike down" problematic agency rules. This has to do with the idea that civil law judiciaries, on which the Chinese judiciary is modelled, are generally expected to apply the law, not to make law. Relatedly, decisions by civil law courts generally do not have precedential value, because they do not create norms of general application. While some modern courts in civil law countries present exceptions to these general rules, the rules continue to characterise the power of most civil law courts. Precluding formal regulations from reinforcement clearly raises suspicions of both law-making (i.e., revoking binding law) and claiming to set precedents, while precluding IPDs from enforcement also sets precedents. This basic logic is supported by the fact that, in civil law countries, the ability of courts to invalidate agency rules seems to be the exception, not the rule. In Germany, for example, an administrative court, when assessing the lawfulness of an agency action, can review a regulation on which such act is based and may rule that it is inconsistent with higher law and therefore void. However, this is not a matter of "striking down" a regulation: it is an assessment of its validity as a preliminary question; such preliminary findings generally do not have any binding effect - not even between the parties to the lawsuit. Similarly, German courts generally do not review informal policy announcements but directly apply the law when assessing the lawfulness of government actions. Any assessment of the lawfulness of an informal rule constitutes a preliminary matter and therefore does not have any binding effect (Panzer 2017: 8; Schmitz 2018: 212-3; Lindner 2018: 302; Scherzberg and Seidl 2014).

This logic also represents the rationale for the set of extraordinary remedies that the 2018 SPC Interpretation delineates for the finding of illegal IPDs: judicial recommendations to the executive branch backed by the threat of retrying cases where problematic IPDs are involved. The unusual character of these remedies (discussed in the next section "Innovations in the 2018 SPC interpretation") arguably results from an effort to enable civil law courts to do what they generally cannot do.

Of course, it is well known among comparative legal scholars that the absence of stare decisis in civil law systems does not necessarily prevent a court decision from having wider impact. In practice, some degree of de facto precedential value may be observed, particularly in decisions of a court of last instance. Judgements can also be endowed with practically binding effect within the executive branch through general administrative instructions. Nothing precludes court decisions from having this kind of effect in China - indeed, increased transparency in adjudication can be expected to strengthen it.

\section{Limitations on pre-enforcement review}

If a court cannot strike down formal or informal agency rules, it should also not hear disputes the main purpose of which is to challenge the validity of such rules - the reviewing court would not be able to provide any remedy. This simple logic already goes a long way toward justifying the nonjusticiability of "abstract administrative actions." Using US terminology, we will label the judicial review of an agency rule before its enforcement "preenforcement review." From a comparative perspective, pre-enforcement review indeed requires extensions of the traditional powers of a civil law court. Again, we offer Germany as an example. The German Code of Administrative Court Procedure ( $\mathrm{W} w \mathrm{CO})$ is widely known for a set of special provisions in Section 47 whereby most state regulations and municipal by-laws are

22. Shanghai Meeting Minutes, Section 1, par. 1.

23. 1989 ALL Article 53, par. 2 .

24. Shanghai Meeting Minutes, Section 2(2)-(4).

25. The SPC clarified in 2000 that "decisions and orders with general binding force" refers to "normative documents" that may be repeatedly used and that are not issued in respect of specific subjects. 2000 SPC Interpretation. This provision was retained in the 2018 SPC Interpretation. 
subject to direct judicial review for up to a year after their enactment. An individual can bring a lawsuit challenging such regulations if $s /$ he can demonstrate that the regulation and its enforcement potentially infringes upon her individual rights. If a higher administrative court finds a regulation to be void, by law, the ruling has effect erga omnes, i.e., not only vis-à-vis the parties to the lawsuit (Giesberts 2018: 65). This establishes an equivalent to precedential value. However, this is precisely understood to be a singular feature of Section 47 direct review, compared to the effect of other court decisions under German law. In contrast, federal regulations cannot be struck down by administrative courts with general effect. Finally, in general, informal policy announcements themselves cannot be subject to judicial pre-enforcement review due to their lack of legal effect. Only the acts based on such announcements will be reviewed by administrational and constitutional courts.

These aspects of German administrative law illustrate the alien nature of pre-enforcement review to civil law courts. However, it is important to emphasise that limitations on pre-enforcement review arise not only in civil law countries. Such review can be rare even in common law jurisdictions. In the United States, pre-enforcement review of federal agency actions is strongly tied to the "notice and comment" procedural requirement for rulemaking under the Administrative Procedure Act (APA). But for the APA, traditional justiciability doctrines would impose substantial restrictions on pre-enforcement review (Landes and Posner 1994). It is now recognised among comparative administrative law scholars that the APA itself is a very American institution, and notice and comment procedures are relatively rare in parliamentary (as opposed to presidential) political systems (Jensen and McGrath 2011; Stiglitz and Figueiredo 2017). In other words, as far as we can tell, the practice of pre-enforcement review of agency regulations is sustained critically by procedural requirements on rulemaking, and these procedural requirements are themselves rare creatures. Consequently, even in common law jurisdictions such as Canada, the UK, and Australia, pre-enforcement reviews are rare.

\section{Scope $v$. standard of review}

The prevalence of these constraints on the "scope of judicial review" in liberal democracies has two implications. First, these constraints do not in themselves render the ALL either exceptional or inadequate. Second, modifying these constraints could involve relatively unusual institutional design, given the parameters of a civil law judiciary (and of a nominally parliamentary system). The $2015 \mathrm{ALL}$ and 2018 SPC Interpretation precisely advance such unusual design. Before discussing this new development, however, it is important to highlight another dimension of judicial review, namely the standard of review that a court should apply in adjudication, especially when the agency action in dispute is based on some interpretation of statutes that the agency favours but which the plaintiff challenges. In many liberal democracies, the standard of judicial review has attracted extensive attention from administrative law practitioners and scholars. By contrast, although the issue has also inevitably arisen in Chinese practice, it has received very limited attention from commentators. Importantly, it is along this neglected dimension that the $2015 \mathrm{ALL}$ and the 2018 SPC Interpretation have dealt a setback to judicial review.

Note from the outset that the standard of review is an important question, regardless of whether the reviewing court is of the civil or common law variety. Regardless of whether a court "merely" determines whether to apply a policy interpretation advocated by the government, or whether the court has the power to invalidate such an interpretation, the court needs to decide the standard to which the government's position must be held. A comparison of four regimes - in China, the US, Canada, and Cermany - suggests that the adoption of this standard depends not at all on constraints on the scope of review.

Under the pre-2015 status quo - mostly articulated through the 2004 Shanghai Meeting Minutes - the standard by which Chinese courts reviewed the purported legal basis of agency actions depended on the nature of the purported basis. If a formal regulation is the ground offered, then a court must determine the regulation's legality before giving it effect. If an IPD is the purported ground, then a court must review its legality and reasonableness/appropriateness before giving it effect. It logically follows that IPDs receive more stringent review and less deference than regulations. However, beyond this, no guidance was offered as to the standards applicable when conducting a review on either legality or reasonableness/appropriateness. Interestingly, this approach bears resemblances to the US federal doctrine on judicial review. US courts' standard of review of agency statutory interpretation also depends on the ways in which an agency's position is developed. When formal regulations (i.e., mostly rules that have gone through the notice and comment procedure required by the APA) are at stake, courts apply the "Chevron test," which in many instances leads to a high level of deference (Merrill and Hickman 2001). By contrast, if only an informal policy position serves as the ground of agency action, courts apply the less deferential "Skidmore standard" (Hickman and Krueger 2007). While under both types of standards, courts have been observed to be more likely to defer to agency actions than not, the varying standards of review (both between the Chevron and Skidmore tests, and within the Chevron test itself) clearly give courts greater interpretive authority in some circumstances than in others. How to characterise these standards thus has been an obsession of US legal scholars (Vermeule 2017; Stack 2018).

By contrast, neither Germany nor Canada distinguishes between formal regulations and informal agency rules in setting standards of review. In Germany, the crucial distinction is between the interpretation and determination of constituent elements of a statutory provision and the exercise of discretion (Arai-Takahashi 2000: 73). With respect to the former, courts generally have full authority to determine the correct interpretation of the law. ${ }^{(26)}$ While court decisions may be influenced by previous administrative interpretations of the law de facto, courts tend not to defer to administrative decisions openly.

Canada, despite having a common law judiciary, takes an approach to statutory interpretation that arguably bears greater affinity to Germany than to the US. Historically, courts frequently applied the "correctness" standard of review to all questions of statutory interpretation, which required little of courts by way of deference. In the seminal Dunsmuir decision in $2008,{ }^{(27)}$ the Supreme Court of Canada indicated that the "correctness standard" should be largely limited to areas where courts have distinctive competence, whereas a reasonableness standard should be applied to the remaining areas. Moreover, there ought to be a presumption of the reason-

26. Deference to the executive's interpretation of laws, including informal policy announcements, is subject to the legislature granting such administrative margin of interpretation (Schmitz 2018: 213). In practice, explicit normative authorisation is rare, and courts are rather reluctant to assume implicit authorisation (Oster 2008: 1271-5; Arai-Takahashi 2000: 75-6; Decker 2018: 35-6).

27. For a recent set of discussions, see Paul Daly, "The Dunsmuir Decade," Administrative Law Matters, 11 January 2018, http://www.administrativelawmatters.com/blog/2018/01/11/the-dunsmuirdecade10-ans-de-dunsmuir/ (accessed on 1 September 2018). 
ableness of agency interpretation, which implies a more deferential view. However, a heavy dose of "contextualism" has led Canadian courts to fashion different subcategories of the reasonableness standard, leading to concerns that many courts engage in a "disguised" correctness review.

Putting aside the richness and high complexity of these administrative law doctrines from different countries, our basic point is that the standard of review is widely regarded in Western democracies as a crucial factor determining the outcomes of judicial review, and that this standard can vary in ways that are independent of whether the judiciary is of a civil or common law character. Just as the Canadian standards of review seem more stringent than the American ones, the German standards of review seem more stringent than the Chinese ones. Nonetheless, it is possible to read into the pre-2015 practice in China a template that resembles the American standards, where courts are entitled to substantial non-deference at least with respect to IPDs. The 2018 SPC Interpretation, however, has fundamentally altered this state of affairs: courts' standard of review of informal agency rules no longer includes reasonableness, and therefore is much weaker and requires courts to display greater deference.

\section{Innovations in the 2018 SPC interpretation}

The $2015 \mathrm{ALL}$ for the first time provides plaintiffs with a right to request that the court review an IPD that the plaintiff deems to be "not in accordance with the law" (bu hefa 不合法), concurrently with reviewing the agency action that serves as the original cause of action and to which the IPD purports to provide legal basis. ${ }^{(28)}$ Such right to review does not extend to formal regulations. ${ }^{29}$ Since courts are still generally required to consider the legality of any relevant formal regulation, the "review" of an IPD must therefore possess a special meaning. Accordingly, a newly added Article 64 of the 2015 ALL provides that if a court deems any IPD to be "not in accordance with the law," then not only should the court not rely on it to determine the legality of the disputed agency action - this was already the case under the pre-2015 law - but the court should also provide the promulgating authority with "disposition recommendations." In other words, the making of "disposition recommendations" (chuli jianyi 处理建议) to the executive branch has become a remedy that a plaintiff may request as a matter of right.

The meaning of this new procedure received important elaboration in the 2018 SPC Interpretation, which contained a separate chapter on the concurrent review of IPDs. First, if a court discovers upon the review of an IPD that it is possibly illegal, it should seek the opinions of the promulgating agency, and give permission to that agency to state its opinion in court. ${ }^{(30)}$ Second, courts are instructed to review the legality of IPDs, and do so with regard to not only the provisions on the basis of which the disputed agency action was taken but also to "related provisions." Specifically, any IPD is "illegal," if it:

[E]xceeds the statutory remit of the promulgating authority, or the scope of delegation provided by statutes and regulations;

contravenes the provisions of any superior law;

illegally increases any obligation, or derogates from any lawful rights and interests, of any private party without appropriate basis in any formal law;

fails to comply with any approval procedures or public issuance procedures stipulated by law, or seriously violates promulgation procedures; or otherwise violates the provisions of statutes of or regulations. (31)
This set of factors represents the first time that the SPC has provided explicit guidance on legality review of IPDs. ${ }^{(32)}$ In particular, the reference in clause (4) to procedures of approval, issuance, and promulgation in general suggests, for the first time, that violating adoption procedures may itself be sufficient grounds for deeming IPDs invalid. However, what types of procedural requirements can be taken into account in the application of clause (4) remains to be seen. ${ }^{(33)}$

Third, consistently with pre-2015 practice, the 2018 SPC Interpretation instructs that illegal IPDs should not be used as the basis for a decision on the challenged agency action. It also instructs that the judgment should make explicit statements about such illegality. ${ }^{(34)}$ Contrary to pre2015 practice, however - and especially overriding the relevant provisions in the 2004 Shanghai Meeting Minutes - the 2018 SPC Interpretation instructs that once an IPD passes the legality test, it should be given legal effect. There is no longer any mention of a "reasonable and appropriate" review. In other words, lawful IPDs are now binding on courts. The standard of review for IPDs is lowered both relative to previous practice, and to comparable US practice (e.g. the Skidmore standard). For advocates of strong judicial review, this can only be viewed as a step backward.

Instead of elaborating the standard of review and strengthening judicial review along this dimension, the 2018 SPC Interpretation offers an unprecedented set of non-judicial remedies, where a reviewing court may initiate a post-adjudication process of communication with the executive branch, sometimes even obliging the latter to take action. Specifically, in the case of an IPD found to be illegal, a court, after entering a decision on the particular dispute, shall issue "disposition recommendations" to the agency promulgating the IPD. It may also copy "the People's government at the same level as the agency, any agency at the next higher level, the supervisory authority, and any recordation authority of the IPD" on the recommendation. (35) Moreover - going beyond what is contemplated in Article 64 of the $2015 \mathrm{ALL}$ - a court may, within three months from the date when the decision takes effect, provide the promulgating authority with "judicial proposals" (sifa jianyi 司法建议) for an amendment or repeal of the IPD. If a court decided to submit such a judicial proposal, an agency receiving the proposal "shall" (yingdang 应当) make a written reply within 60 days from the date of receipt of the proposal. In the case of emergency, a court may even propose that the promulgating authority, or the agency at the next higher level, immediately suspend the enforcement of the IPD.

The power of the judiciary to propose the amendment or revocation of IPDs (albeit only ones that are not in accordance with law) seems extraordinary. It is indeed unclear what basis a court has for imposing an obligation on the executive branch to respond. As if to strengthen its power to do so, the 2018 SPC Interpretation provides that if a court deems an IPD to be

28. 2015 ALL Article 53, par. 1.

29. Ibid., par. 2 .

30. 2018 SPC Interpretation Article 147.

31. Ibid., Article 148.

32. However, such guidance presumably does not apply to the review of the legality of formal regulations.

33. There are also no known statutory procedures for the promulgation of IPDs; there are at best some formal regulations that stipulate such procedures (Cui 2011). Many procedural requirements for the adoption of IPDs are, ironically, set out in informal bureaucratic documents.

34. 2018 SPC Interpretation, Article 149.

35. Ibid. 
Table 1 - Remedies for the review of formal and informal agency rules

\begin{tabular}{|c|c|c|}
\hline & Pre-2015 & 2015 and after \\
\hline $\begin{array}{l}\text { Illegal regulations or IPDs as cause of } \\
\text { action }\end{array}$ & No & No \\
\hline $\begin{array}{l}\text { Illegal regulations and IPDs not to be } \\
\text { applied }\end{array}$ & Yes & Yes: new instructions on IPD legality review \\
\hline $\begin{array}{l}\text { Unreasonable or inappropriate IPDs not } \\
\text { to be applied }\end{array}$ & Yes & No: court must give effect to legal IPDs \\
\hline $\begin{array}{l}\text { Post-adjudication procedures for } \\
\text { recommendations to executive branch }\end{array}$ & No & $\begin{array}{l}\text { Yes: } \\
\text { - Mandatory disposition recommendations } \\
\text { - Optional judicial recommendations to amend or repeal } \\
\text { (to which promulgating agencies must respond) } \\
\text { - Optional recommendations for suspension of enforcement }\end{array}$ \\
\hline $\begin{array}{l}\text { Post-adjudication procedures for filing } \\
\text { with higher courts }\end{array}$ & No & Yes: Mandatory recording of illegal IPDs \\
\hline $\begin{array}{l}\text { Right of higher courts to retry cases } \\
\text { based on illegal IPDs }\end{array}$ & No & Yes \\
\hline
\end{tabular}

legally invalid, it is required to file the decision (post adjudication) with the court at the next higher level for the record. ${ }^{(36)}$ Moreover, if an IPD promulgated by a department of the State Council or a provincial agency is involved, any judicial proposal made to the executive branch should also be submitted to provincial high courts and the SPC for record. ${ }^{(37)}$ This seems to ensure that the finding of an illegal IPD will be escalated within the judiciary, and that first-instance courts are not left to their own devices to pursue the (rather entrepreneurial) undertaking of issuing recommendations to the executive branch.

The filing of decisions and proposals with higher courts also potentially facilitates a final set of remedies. The 2018 SPC Interpretation provides that "where the president of a court at any level discovers that any effective judgment or ruling of the court erroneously determined the legality of an IPD, and deems that a retrial is necessary, he/she would make a referral to the adjudication committee of the court for discussion." (38) Moreover, "if the SPC or any superior court discovers that an effective judgment or ruling of a lower court erroneously determined the legality of an IPD, it (the SPC or superior court) has the authority to conduct a retrial or to appoint a subordinate court to do so." (39) The ability of the judiciary to re-open cases that implicate controversial executive branch policy seems to provide an important incentive for agencies to respond to recommendations from the judiciary. Table 1 summarises these extraordinary measures.

\section{Conclusion}

Overall, recent developments seem to have considerably strengthened the institutions for carrying out judicial review of government actions in China, in at least two respects. First, this has been a period of dynamic doctrinal elaboration, of which the 2018 SPC Interpretation can be seen as a capstone, but in relation to which the unprecedented disclosure of court decisions is perhaps even more significant (Liebman et al. 2017). Second, judicial review is increasingly conducted by higher courts - including important new (supraprovincial) circuit courts and (provincial) cross-district courts. Even aside from the allocation of new institutional resources, an $87 \%$ increase in firstinstance cases and 200\% increase in appeals, accompanied by little court backlog and a sizeable increase in the percentage of adjudicated cases, provide prima facie evidence for greater efficiency in court operations.

However, for several reasons, one must be cautious in drawing conclusions from these descriptions. First, much scholarly discussion in China about judicial review has engaged with proposals to revise the ALL, yet the ALL's revision is, as we tried to show, clearly a matter of top-down institutional design, driven visibly by a small group of actors in the SPC and NPCSC. The question can be raised as to whether this sociological origin of the discourse on ALL has affected its content. For example, radical proposals that lack clear functional justification but that accentuate the symbolism of judicial review - such as creating a separate administrative court system, requiring agency chiefs to appear in court, and emboldening judges to constrain executive branch rulemaking - seem to attract perennial interest. At the same time, basic facts about how the thousands of court administrative divisions across China have handled cases tend to remain obscure - with the SPC acting as one of the few sources of information. Indeed, even the well-known "three difficulties" of bringing suits against agency defendants are not well-documented empirically: empirical accounts of what proportion of lawsuits had been declined by courts at the

\footnotetext{
36. 2018 SPC Interpretation, Article 150.

37. Ibid.

38. Ibid., Article 151, par. 1

39. Presumably, this type of retrial can be triggered both when the error involved was determining a legally invalid IPD to be valid, and when a legally valid IPD was determined to be invalid.
} 
outset, for example, vary widely in their estimates. Therefore, it is important - especially for Western commentators - to recognise the existence of these gaps and not to conflate a stylised discourse on administrative litigation with its reality.

Second, Chinese scholars and policymakers have yet to articulate a normative framework for conceptualising what forms enhanced judicial power should take. Should it, for example, be courts' frequent use of various sanctions of agency misconduct in the course of litigation, of the power to make judicial recommendations for amending or repealing illegal IPDs, or of the authority to retry cases? Or should it, again for example, be the ability of individual judges to introduce policy considerations into adjudication through reviewing the reasonableness of IPDs (which the Shanghai Meeting Minutes contemplated but which the 2018 SPC Interpretation seems to abolish)? An important and common theme in contemporary administrative law scholarship in liberal democracies is how to preserve the integrity of judicial review while recognising the limitations of the judiciary within the modern state in the interpretation and enforcement of policy (Merrill and Hickman 2001; Hickman and Krueger 2007; Vermeule 2017; Stack 2018; Arai-Takahashi 2000; Schmitz 2018; Oster 2008; Decker 2018; Daly 2018). Arguably, this theme has largely been absent from Chinese discourse in reforming the ALL.

Third and finally, many commentators on Chinese administrative litigation may intuitively associate increasing judicial strength with political liberalisation (Cui 2017: 992-6): judicial independence is interesting because it increases the chances of political liberalisation. However, a different perspective is that an adequately functioning judiciary only represents an aspect of state capacity, and even authoritarian regimes can display strong state capacity (Albertus and Menaldo 2017). From this latter perspective, even an unquestioned strengthening of judicial review in China may bear little implication for Chinese politics. Exploring this perspective is beyond the scope of this paper: after all, the tendency to conflate judicial review with particular normative visions is not unique to China. ${ }^{(40)}$ But the possibility of such a perspective is an important reason not to presuppose that judicial review must have political significance.

\section{Wei Cui is Professor at the Peter A. Allard School of Law and} Director of University of British Columbia Centre for Asian Studies (cui@allard.ubc.ca).

1 Jie Cheng is an Associate professor at Tsinghua Law School.

Dominika Wiesner is a PhD student at the Peter A. Allard School of Law, University of British Columbia.

Article received on 9 June 2018. Accepted on 21 January 2019.

40. For instance, Vermeule laments much "wasted energy" directed against the Chevron doctrine in the US (which delineates permissible judicial deference to the executive branch), motivated (among other things) by "a fervent, if cockeyed, constitutional vision [or by] free-market libertarianism" (Vermeule 2017).

\section{References \\ Academic Sources in Chinese language}

GAO, Jinghong 高憬宏. 2015. “法官员额制的制度价值和实现路径” (Faguan yuan'e zhi de zhidu jiazhi he shixian lujing, The institutional value and implementation path of quota system for judges). 人民法院报 (Renmin Fayuan Bao, People's Court Daily), 15 July 2015.

HU, Jianmiao 胡建水, and TANG Zhen 唐震. 2011. “行政诉讼调解、和解 抑或协调和解: 基于经验事实和规范文本的考量" (Xingzheng susong tiaojie, hejie, huo xietiao hejie: jiyu jingyan shishi he guifan wenben de kaoliang, Mediation, reconciliation, or coordinated reconciliation in administrative litigation: considerations based on empirical facts and standard documents). 政法论坛 (Zhengfa Luntan, Journal of Political Science and Law) 29(4): 52-61.

JIANG, Bixin 江必新 (ed.). 2005. 中国行政诉讼的完善 (Zhongguo xingzheng susong de wanshan, Perfection of China's administrative litigation system: a practical study for an ALL revision). Beijing: Law Press (Falü Chubanshe 法律出版社).

JIANG, Bixin 江必新. 2013. “完善行政诉讼制度的若干思考” (Wanshan xingzheng susong zhidu de ruogan sikao, Several thoughts on perfecting the administrative litigation institution). 中国法学 (Zhongguo Faxue, China Legal Science) 1: 5-20.

JIN, Song 晋松. 2014. “困惑与突破：环境司法保护的诉讼模式一基于行政 公益诉讼制度构建的反思” (Kunhuo yu tupo: huanjing sifa baohu de susong moshi - jiyu xingzheng gongyi susong zhidu jiangou de fansi, Difficulty and breakthrough: The litigation model of environmental judicial protection - reflection based on the construction of the public interest administrative litigation institution). 法律适用 (Falü Shiyong, Journal of Law Application) 2:69-74.

JING, Hanchao 景汉朝 (ed.). 2010. 司法成本与司法效率实证研究 (Sifa chengben yu sifa xiaolü shizheng yanjiu, Empirical studies of judicial cost and judicial efficiency). Beijing: China University of Political Science and Law Press (Zhongguo Zhengfa Daxue Chubanshe 中国政法大学出版社).
LI, Guangyu 李广宇, and WANG Zhenyu 王振宇. 2012. “行政诉讼类型化: 完善行政诉讼制度的新思路" (Xingzheng susong leixinghua: wanshan xingzheng susong zhidu de xin silu, Categorization of administrative litigation: new approach to the development and refinement of the administrative litigation institution). 法律适用 (Falü Shiyong, Journal of Law Application) 2: 9-14.

LI, Guangyu 李广宇, LIANG Fengyun 梁凤云, and WANG Zhenyu 王振宇. 2013. “行政诉讼法修改应关注十大问题” (Xingzheng susongfa xiugai ying guanzhu shida wenti, We should pay close attention to ten major issues in the amendment of Administrative Litigation Law). 法律适用 (Falü Shiyong, Journal of Law Application) 3:69-73.

LI, Peilei 李培否. 2016."2014-2015年行政诉讼制度改革一以《行政诉公 法》修改和实施为中心” (2014-2015 nian xingzheng susong zhidu gaige -Yi "xingzheng susongfa" xiugai he shishi wei zhongxin, Reform of the administrative litigation institution from 2014 to 2015 - With a focus on the amendment and implementation of "Administrative Litigation Law"). 行政法学研究 (Xingzheng Faxue Yanjiu, Administrative Law Review) 2: 109-21, 135.

LIN, Lihong 林莉红, and SONG Guotao 宋国涛. 2013. “中国行政审判法官 的知与行一《行政诉讼法》实施状况调查报告. 法官卷” (Zhongguo xingzheng shenpan faguan de zhi yu xing - "Xingzheng susongfa" shishi zhuangkuang diaocha baogao: Faguan juan, Knowledge and Conduct of China's Judges for Administrative Adjudication - Investigative Report on the Implementation Results of Administrative Litigation Law: Volume on Judges). 行政法学研究 (Xingzheng Faxue Yanjiu, Administrative Law Review) 2: 49-62.

QIAO, Xiaoyang 乔晓阳. 2014. 全国人民代表大会法律委员会关于《中华 人民共和国行政诉讼法修正案（草案）》审议结果的报告 (Quanguo renmin daibiao dahui falü weiyuanhui guanyu "Zhonghua renmin gongheguo xingzheng susongfa xiuzheng'an (cao'an)" shenyi jieguo de baogao, Report by the Law Committee of the National People's Congress on the deliberation results of the "Proposed Amendment of the Administrative Litigation Law of the People's Republic of China (Draft)"). 
TONG, Weidong 童卫东. 2015. “进步与妥协: 《行政诉讼法》修改回顾” (Jinbu yu tuoxie: "xingzheng susongfa" xiugai huigu, Progress and compromise: A look back on the amendment of Administrative Litigation Law). 行 政法学研究 (Xingzheng Faxue Yanjiu, Administrative Law Review) 4: 2232.

ZHANG, Zhiyuan 章志远. 2015. “晚近十年的中国行政诉讼学研究” (Wan jin shinian de Zhongguo xingzheng susongxue yanjiu, Research of China's administrative litigation in the last ten years). 清华法学 (Qinghua Faxue, Tsinghua Law Journal) 1:63-80.

\section{Academic Sources in English Language}

ALBERTUS, Michael, and Victor MENALDO. 2017. Authoritarianism and the Elite Origins of Democracy. Cambridge: Cambridge University Press.

ARAI-TAKAHASHI, Yutaka. 2000. "Discretion in German Administrative Law: Doctrinal Discourse Revisited." European Public Law 6(1): 69-80.

CUI, Wei, and Zhiyuan WANG. 2017. "The Selection of Litigation against Government Agencies: Evidence from China." Review of Law and Economics 13(3): 1-41.

CUI, Wei. 2011. "What Is the 'Law' in Chinese Tax Administration?" Asia Pacific Law Review 19(1): 75-94.

CUI, Wei. 2017. "Does Judicial Independence Matter? A Study of the Determinants of Litigation Patterns in an Authoritarian Regime." University of Pennsylvania Journal of International Law 38(3): 941-98.

HE, Haibo. 2018. "How Much Progress Can Legislation Bring: The 2014 Amendment of the Administrative Litigation Law of PRC." University of Pennsylvania Asian Law Review 13(1): 137-90.

HICKMAN, Kristin, and Matthew D. KRUEGER. 2007. "In Search of the Modern Skidmore Standard." Columbia Law Review 107(6): 1235-320.

JENSEN, Christian B., and Robert J. MCGRATH. 2011. "Making Rules about Rulemaking; A Comparison of Presidential and Parliamentary Systems." Political Research Quarterly 64(3): 656-67.

LANDES, William M., and Richard A. POSNER. 1994. "The Economics of Anticipatory Adjudication." The Journal of Legal Studies 23(2): 683-719.

LIEBMAN, Benjamin L. et al. 2017. "Mass Digitization of Chinese Court Decisions: How to Use Text as Data in the Field of Chinese Law." $21^{\text {st }}$ Century China Center Research Paper No. 01.

MERRILL, Thomas W., and Kristin E. HICKMAN. 2001. "Chevron's Domain." Georgetown Law Journal 89(4): 833-921.

OSTER, Jan. 2008. "The Scope of Judicial Review in the German and U.S Administrative Legal System." German Law Journal 9(10): 1267-97.

SCHERZBERG, Arno, and Josephine SEIDL. 2014. "Administrative Litigation in Germany." InYuwen Li (ed.), Administrative Litigation Systems in Greater China and Europe. New York: Routledge. 141-62.

STACK, Kevin M. 2018. "Overcoming Dicey in Administrative Law." University of Toronto Law Journal 68(2): 293-311.

STIGLITZ, Edward H., and John M. de FIGUEIREDO. 2017. "Democratic Rulemaking." In Francesco Parisi (ed.), The Oxford Handbook of Law and Economics, Volume 3. Oxford: Oxford University Press.

VERMEULE, Adrian. 2017. "Chevron as a Legal Framework." JOTWELL 2017 $1-3$.

\section{Academic Sources in German Language}

DECKER, Andreas. 2018. "§ 114 [Nachprüfung von Ermessensentscheidungen]." In Herbert Posser, and Heinrich Amadeus (eds.), Wolff BeckOK VwGO, $44^{\text {th }}$ edition. Munich:Verlag C.H.BECK.
GIESBERTS, Ludger. 2018. "§ 47 [Sachliche Zuständigkeit des Oberverwaltungsgerichts bei der Normenkontrolle]." In Herbert Posser, and Heinrich Amadeus (eds.), Wolff BeckOK VwGO, 44 ${ }^{\text {th }}$ edition. Munich: Verlag C.H.BECK.

LINDNER, Josef F. 2018. "§ 121 [Rechtskraft]." In Herbert Posser, and Hein-

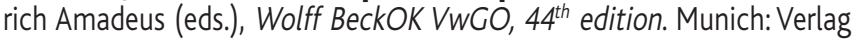
C.H.BECK.

PANZER, Nicolai. 2017. "§ 47 [Sachliche Zuständigkeit des OVG bei der Normenkontrolle]." In Friedrich Schoch, Jens-Peter Schneider, and Wolfgang Bier (eds.), Schoch/Schneider/BierVerwaltungsgerichtsordnung Kommentar, supplement 33. Munich:Verlag C.H.BECK.

SCHMITZ, Heribert. 2018. "§ 1 Anwendungsbereich." In Michael Sachs, and Heribert Schmitz (eds.), Stelkens/Bonk/Sachs Verwaltungsverfahrensgesetz Kommentar, $9^{\text {th }}$ edition. Munich:Verlag C.H.BECK.

\section{Primary Sources in Chinese Language}

最高人民法院关于执行《中华人民共和国行政诉讼法》若干问题的解释 (法释[2000] 8号) (Zuigao renmin fayuan guanyu zhixing "Zhonghua renmin gongheguo xingzheng susongfa" ruogan wenti de jieshi (Fashi [2000] 8 hao), 2000 SPC interpretation on issues regarding enforcement of ALL (replaced by 2018 Interpretation)).

最高人民法院关于印发《关于审理行政案件适用法律规范问题的座谈会 纪要》的通知 (法 [2004] 96号) (Zuigao renmin fayuan guanyu yinfa "Guanyu shenli xingzheng anjian shiyong falü guifan wenti de zuotanhui jiyao" de tongzhi (Fa [2004] 96 hao), 2004 Minutes of the symposiums of the Supreme People's Court concerning application of laws in adjudicating administrative cases ("Shanghai Meeting Minutes")).

最高人民法院关于开展行政案件相对集中管辖试点工作的通知 (法 [2013] 3 号) (Zuigao renmin fayuan guanyu kaizhan xingzheng anjian xiangdui jizhong guanxia shidian gongzuo de tongzhi (Fa [2013] 3 hao), 2013 SPC notice of carrying out the pilot work of administrative cases in a relatively centralised jurisdiction).

最高人民法院关于人民法院跨行政区域集中管辖行政案件的指导意见 (法 [2015] 8号) (Zuigao renmin fayuan guanyu renmin fayuan kua xingzheng quyu jizhong guanxia xingzheng anjian de zhidao yijian (Fa [2015] 8 hao), 2014 SPC guiding opinion on cross administrative regions centralised adjudication of administrative cases).

关于深化司法体制和社会体制改革的意见及贯彻实施分工方案 (中央深改 组第二次会议) (中办发 [2014] 24号) (Guanyu shenhua sifa tizhi he shehui tizhi gaige de yijian ji guanche shishi fengong fang'an (Zhongyang shengaizu di'erci huiyi) (Zhongbanfa [2014] 24 hao), 2014 LGCDR opinions and division of labour to enforce deepening judicial and social reform).

最高人民法院关于适用《中华人民共和国行政诉讼法》若干问题的解释 (法释[2015] 9号) (Zuigao renmin fayuan guanyu shiyong "Zhonghua renmin gongheguo xingzheng susongfa" ruogan wenti de jieshi (Fashi [2015] 9 hao), 2015 Interpretation of the Supreme People's Court on several issues concerning the application of the Administrative Litigation Law of the People's Republic of China (abolished and replaced by 2018 Interpretation)).

最高人民法院关于适用《中华人民共和国行政诉讼法》的解释 (法释 [2018] 1号) (Zuigao renmin fayuan guanyu shiyong "Zhonghua renmin gongheguo xingzheng susong fa" de jieshi (Fashi [2018] 1 hao), 2018 Interpretation of the Supreme People's Court on application of the Administrative Litigation Law of the People's Republic of China "2018 SPC Interpretation"). 